Rev. Int. Contam. Ambie. 37, 55-66, 2021

https://doi.org/10.20937/RICA.53676

\title{
PHOTOCATALYTIC SOLAR OXIDATION OF ACESULFAME-K. EFFECT OF INITIAL pH, CATALYST DOSE AND OXIDANT CONCENTRATION
}

Oxidación fotocatalítica solar de acesulfamo-K. Efecto del pH, la dosis de catalizador y la concentración de oxidante

Julio César MORALES MEJÍA ${ }^{1 *}$, Karla Ibette ANSELMO CERVANTES ${ }^{1}$, Iván GARCÍA MENDOZA ${ }^{1}$ and Rafael ALMANZA ${ }^{2}$

\footnotetext{
${ }^{1}$ Universidad Nacional Autónoma de México, Facultad de Estudios Superiores Cuautitlán, Sección de Ingeniería Química. Av. 1 o de mayo s/n, Santa María las Torres, campo uno, 54740 Cuautitlán Izcalli, Estado de México, México.

${ }^{2}$ Universidad Nacional Autónoma de México, Instituto de Ingeniería, Coordinación de Mecánica y Energía, Circuito Exterior s/n, Ciudad Universitaria, 04510 Ciudad de México, México.
}

*Author for correspondence: mmjc_80@yahoo.com.mx

(Received: July 2019; accepted: April 2020)

Key words: CPC, solar photocatalysis, $\mathrm{TiO}_{2}$, water, acesulfame-K.

\begin{abstract}
Aqueous acesulfame-K was oxidized in a pilot solar photocatalytic reactor, equipped with a compound parabolic collector (CPC). The reactor has an area of $0.40 \mathrm{~m}^{2}$ of CPC collectors with geometrical concentration ratio of 1 and a simple mechanical configuration. The experiments of photocatalytic oxidation of acesulfame-K were performed by treating $2 \mathrm{~L}$ of water with an initial concentration of $15 \mathrm{mg} / \mathrm{L}$. The photocatalyst used was P25 (Aeroxide $\mathrm{TiO}_{2}$ ) from Evonik. One of the goals of the research work was to find a set of conditions to efficiently remove this emerging concern pollutant. Results allowed proposing a set of reaction conditions that lead to a high removal of acesulfame-K. In addition, the experimental design allowed determining the effect of initial $\mathrm{pH}$ as well as the impact of initial concentrations of photocatalyst and chemical oxidant. The removal efficiency of acesulfame-K and related UV-absorbing species reached values up to $96-99 \%$ and there was not a quantifiable amount of intermediate products (analyzed as UV absorbing species). Despite reaction time was fixed in $3 \mathrm{~h}$ for all the experiments, oxidation efficiencies higher than $95 \%$ were reached at $2 \mathrm{~h}$ of reaction or even before.
\end{abstract}

Palabras clave: $\mathrm{CPC}$, fotocatálisis solar, $\mathrm{TiO}_{2}$, agua, acesulfamo-K.

\section{RESUMEN}

Se oxidó el acesulfamo-K acuoso en un reactor fotocatalítico solar piloto equipado con un colector de parábola compuesta (CPC, por sus siglas en inglés). El reactor tiene un área de $0.40 \mathrm{~m}^{2}$ de colectores CPC, con una relación de concentración geométrica de 1 y una configuración mecánica simple. Los experimentos de oxidación fotocatalítica de acesulfamo-K se realizaron mediante el tratamiento de $2 \mathrm{~L}$ de agua con una concentración inicial de $15 \mathrm{mg} / \mathrm{L}$. El fotocatalizador utilizado fue P25 (Aeroxide $\left.\mathrm{TiO}_{2}\right)$ de 
Evonik. Uno de los objetivos del trabajo de investigación fue encontrar un conjunto de condiciones para eliminar eficientemente este contaminante de preocupación emergente. Los resultados permitieron proponer un conjunto de condiciones de reacción que conducen a una alta eliminación de acesulfamo-K. Además, el diseño experimental permitió determinar el efecto del $\mathrm{pH}$ inicial, así como el de las concentraciones iniciales del fotocatalizador y el oxidante químico. La eficiencia de eliminación de acesulfamoK y especies relacionadas absorbentes de UV, alcanzó valores de hasta 96-99 \% y no se observaron cantidades cuantificables de productos intermedios (analizados también como especies absorbentes de UV). A pesar de que el tiempo de reacción se fijó en 3 $\mathrm{h}$ para todos los experimentos, se alcanzaron eficiencias de oxidación superiores al 95 $\%$ a las $2 \mathrm{~h}$ de reacción o incluso antes.

\section{INTRODUCTION}

Artificial sweeteners are widely used all around the world. The main non-caloric artificial sweeteners are saccharin, aspartame, acesulfame potassium (acesulfame-K), sucralose, neotame, advantame, steviol glycosides and Luo Han Guo fruit extracts (FDA 2018). Acesulfame-K (Fig. 1) is an artificial non-caloric sweetener that is 200 times sweeter than table sugar and is used in diet beverages and baked products because it is resistant to temperature and chemically stable.
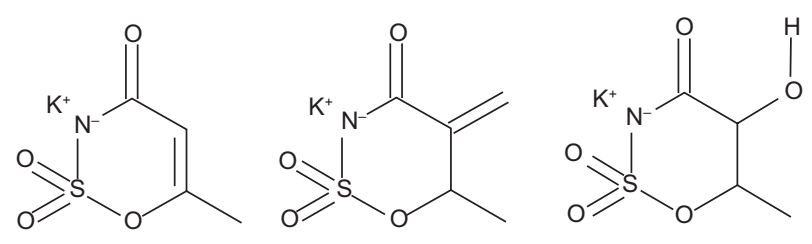

Ace-K
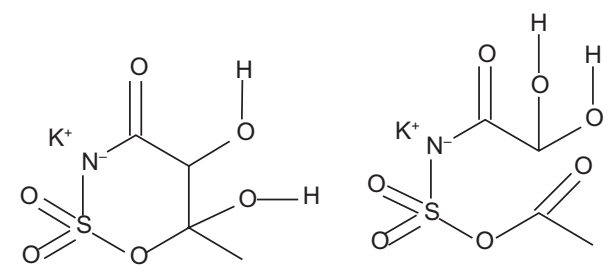

Fig. 1. Acesulfame-K and important photolysis products from its molecule (based on Gan et al. 2014 and Scheurer et al. 2014).

The consumption of non-caloric sweeteners is very common. As an example, in a survey performed in 2016 in France, more than 1.5 million people said they used an artificial sweetener 2-3 times a day and 1.75 million people indicated they consumed these products once a day (Statista 2018). In the USA, it is estimated that $25 \%$ of children and $41 \%$ of adults consumed foods and beverages containing lowcalories sweeteners just during 2016, mainly with a once a day consumption (Sylvetsky et al. 2017). It is estimated that 2.898 million tons of non-caloric sweeteners were consumed just during the period 2002-2003 in Mexico (SE 2018).

Acesulfame-K has been found on discharged waters in Spain (up to $53.7 \mu \mathrm{g} / \mathrm{L}$ ), Hong-Kong (0.22 $\mu \mathrm{g} / \mathrm{L})$, Canada $(33.6 \mu \mathrm{g} / \mathrm{L})$, China $(11 \mu \mathrm{g} / \mathrm{L})$, etc.; also, the sweetener has been found in surface waters of two water bodies in China at 3.5 to $11.5 \mu \mathrm{g} / \mathrm{L}$ (Gan et al. 2013, Sang et al. 2014). In Mexico, acesulfame$\mathrm{K}$ is widely used and discharged to wastewaters, but there is a vacancy of studies about its presence and concentration in water (surface or underground). Only one research publication about this topic was found (Moeder et al. 2017) at the moment of writing this document, where authors monitored concentration of acesulfame-K along a vegetated ditch in Sinaloa state during a complete year. They found the highest concentrations at the three sampling points closest to populated areas $(3.023,2.350,2.539 \mu \mathrm{g} / \mathrm{L})$. Results of these and similar researches indicate that the presence and persistence of this pollutant in environment is of concern.

The $\mathrm{pH}$ in run-off water and wastewater can be lowered by acidic rain. In very acidic conditions ( $\mathrm{pH}=2.5$ ), acesulfame- $\mathrm{K}$ is slightly decomposed by hydrolysis and it produces acetoacetamide and acetoacetamide-N-sulfonic acid. On the other way, at neutral and basic conditions $(\mathrm{pH}=3-10.5)$, acetoacetic acid and acetoacetamide-N-sulfonic acid have been detected from acesulfame-K decomposition (Sang et al. 2014, IPCS 2018).

If artificial sweeteners pose a risk or not for humans and/or other organisms is a subject of ongoing discussion. Despite there are no consistent studies about the potential effects of acesulfame- $K$ as an environmental pollutant, some studies indicate probable adverse effects when this sweetener reaches 
the environment. Cruz-Rojas et al. (2019) exposed common carps to acesulfame- $\mathrm{K}$ and they found that this sweetener can reach blood, gill, liver, brain and muscle before $72 \mathrm{~h}$ of exposure at $0.05 \mu \mathrm{g} / \mathrm{L}$ of acesulfame- $\mathrm{K}$, and it reaches the same target organs during $12 \mathrm{~h}$ of exposure under $149 \mu \mathrm{g} / \mathrm{L}$. In addition, these authors determined that this molecule caused oxidative stress in the carps after exposures from 12 $\mathrm{h}$, with 0.05 and $149 \mu \mathrm{g} / \mathrm{L}$ of the sweetener. Acesulfame- $\mathrm{K}$ is not absorbed or metabolized by human's digestive system. It reaches environment by urine and undergoes chemical changes due to light (Gan et al. 2014) or bacteria. It was reported that UV irradiance (from a lamp and from sunlight) can transform acesulfame-K to iso-acesulfame and to a hydroxylated acesulfame (Scheurer et al. 2014). Even more, if $\mathrm{pH}$ is acidic, the rate of transformation under natural UV light is really higher than at neutral $\mathrm{pH}$, with $\mathrm{t}_{50}$ (required time to have $50 \%$ of the parent molecule transformed) around 7 days for non-sterile samples. A proposed main chemical reaction route during photolysis of acesulfame- $\mathrm{K}$ is shown in figure $\mathbf{2}$ (Gan et al. 2014).

Heterogeneous photocatalysis is an advanced oxidation process based on the photonic activation of a catalyst (usually titanium dioxide or related materials). Either the reaction mechanisms of photocatalytic oxidation and the kinetics aspects, as well as several environmental applications for water and air detoxifying, have been widely reported (Blanco 2003, Herrmann 2005, Li-Puma 2005, Herrmann 2010, Morales-Mejía et al. 2013, Morales-Mejía 2014a, Hernández-Colorado et al. 2017, etc.). As a short explanation of its fundamentals, it can be stated that a photon has to hit an electron at the semiconductor (photocatalyst) surface with energy higher than the bandgap energy of the catalyst, causing the electron to move to the conduction layer of this material leaving a vacancy (photo-hole) in valence band. Both the excited electron and the photo-hole can interact with their environment (water, air, etc.) and produce oxidizing chemical species, like hydroxyl and super oxygen radicals. On the other hand, the excited electron and the photo-hole can recombine, making the catalyst inactive. In order to avoid this recombination, an electron acceptor must be present inside the reactor chamber (Herrmann 2005, 2010). The choice of the oxidizer is important. Nezar and Laoufi (2018) compared the usage of $\mathrm{H}_{2} \mathrm{O}_{2}, \mathrm{~K}_{2} \mathrm{~S}_{2} \mathrm{O}_{7}$ and $\mathrm{Na}_{2} \mathrm{~S}_{2} \mathrm{O}_{7}$ as electron acceptor (electron scavenger) for photocatalytic oxidation of metformin, with $\mathrm{P} 25 \mathrm{TiO}_{2}$; they found that sodium persulfate $\left(\mathrm{Na}_{2} \mathrm{~S}_{2} \mathrm{O}_{7}\right)$ produced the highest kinetic constants and efficiencies. For air and water detoxification, hydroxyl is the most important radical, mainly obtained from water molecules at active sites on the catalyst surface that is irradiated.

The most studied and reported photocatalyst has been $\mathrm{TiO}_{2}$, mainly because of its high chemical and physical stability and its availability all around the world. Pure white $\mathrm{TiO}_{2}$ nanoparticles are activated only under UV irradiance due to its conventional bandgap energy of around $3.2 \mathrm{eV}$. This value means that solar energy is useful for activating the catalyst only partially, since its light spectrum contains only 3-5 \% of UV radiation. Several efforts have been done to produce stable, effective and affordable photo-catalysts that are active under visible light. However, these desirable characteristics of any photocatalyst have not been placed together in a single material yet. Of course, the doped catalysts can be activated under visible light and usually present high conversion efficiencies on removing organic pollutants, but these catalytic materials might be expensive or chemically instable (Lee et al. 2009, Colón et al. 2010, Ma et al. 2011, Wang et al. 2011, 2016, Albrbar et al. 2016, Arzate-Salgado et al. 2016, Gosh et al. 2018a, Khan et al. 2018, Durán-Álvarez et al. 2019, etc.). Considering this, pure $\mathrm{TiO}_{2}$ is still an important photocatalytic material because it has proven to be effective and affordable.

Acesulfame $\mathrm{K}$ is an emerging concern pollutant of water. Due to its ubiquitous occurrence, it has been proposed as a chemical marker for pollutants in underground water (Buerge et al. 2009). The effects of the parent molecule (and of intermediates from its photolysis) on fauna and flora should be of concern because these molecules must not be present on environment. The removal of acesulfame- $\mathrm{K}$ by heterogeneous photocatalysis has been studied and presented just in a few publications. Jing-Li et al. (2016), Gosh et al. (2018b) and López-Muñoz et al. (2018) worked on photocatalytic oxidation of an aqueous solution of this compound, but their experiments have been performed at laboratory bench, with small water volume and under UV irradiances that are very different than those from the Sun. Photocatalytic reactors are considered as a promising technology to successfully oxidize this emerging concern pollutant, for water detoxifying, but there is not available information at the present day about the oxidation of acesulfame-K in pilot size reactors working with real solar irradiance, which is the research area of the present work: the effects of initial $\mathrm{pH}$, initial oxidant concentration and catalyst load on the solar photocatalytic oxidation of aqueous acesulfame-K inside a CPC photocatalytic reactor. 


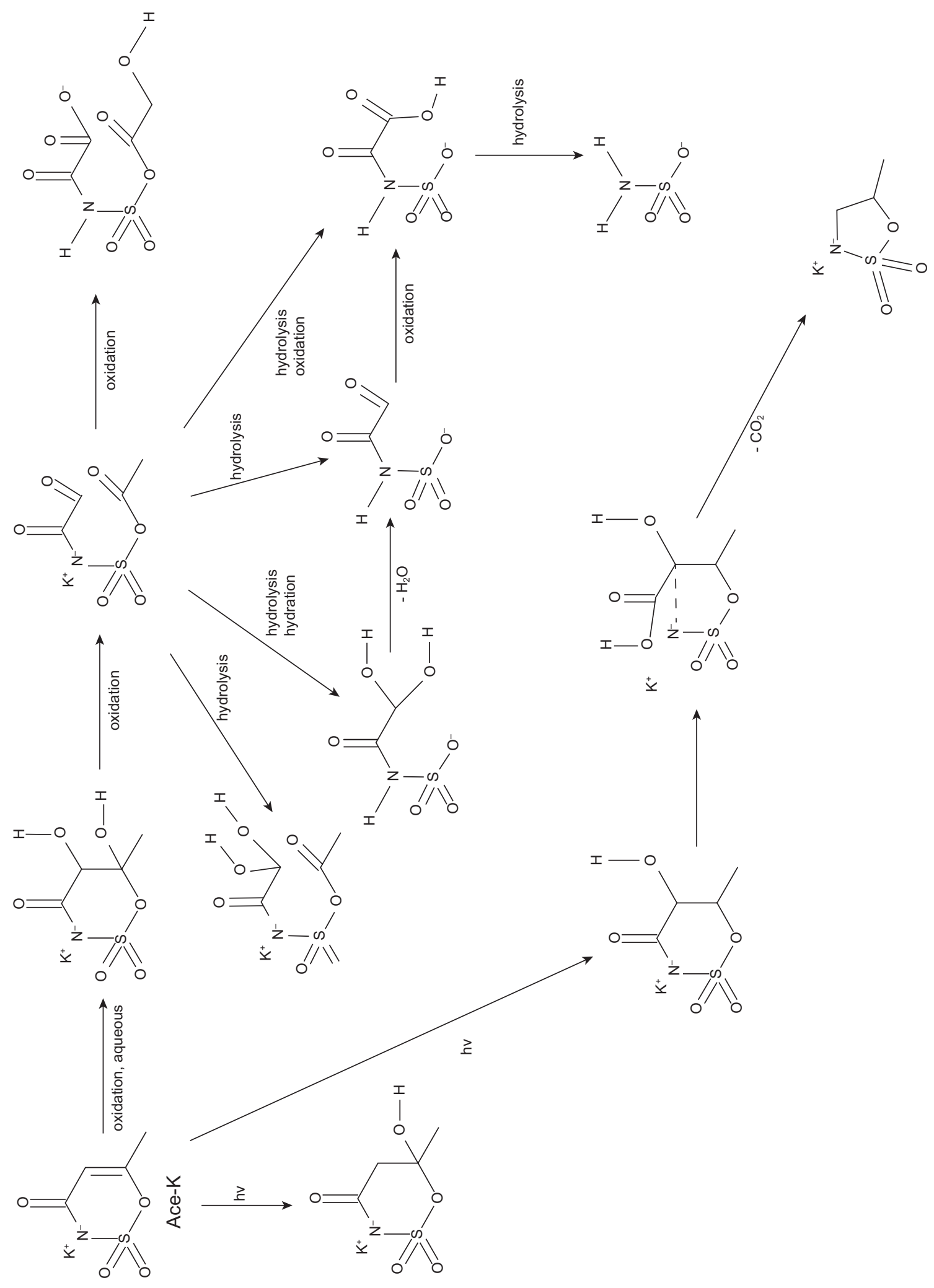

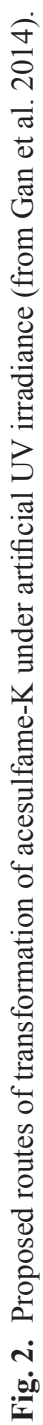




\section{EXPERIMENTAL METHOD}

Experiments consisted of photocatalytic solar oxidations of $2 \mathrm{~L}$ of aqueous acesulfame- $\mathrm{K}(\mathrm{Co}=$ $15 \mathrm{mg} / \mathrm{L}$ ) while initial $\mathrm{pH}$ values, as well as initial concentrations of photocatalyst and electron acceptor (chemical oxidant), were all varied on the basis of a factorial experimental design: for three initial P25 concentrations $(0.05,0.1$ and $0.2 \mathrm{~g} / \mathrm{L})$, three initial concentrations of persulfate were fixed $(0.1,0.25$ and $0.5 \mathrm{mM}$ ). In addition, three different initial $\mathrm{pH}$ values were adjusted at the beginning of the test for every combination of P25 and persulfate. Each of the experiments was repeated twice, scheme that resulted on 54 experiments.

The measured variable was spectral absorbance (spectrum from 200 to $900 \mathrm{~nm}$ ) of filtered samples. A complementary variable was UV solar irradiance over the reactor plane. UV irradiance is the base for kinetics analysis, then the efficiencies are fitted against UV energy over the reactor instead of fitting them against reaction time, as it has been widely used (Blanco 2003, Morales-Mejía 2014b).

Additionally, X-Ray diffraction (XRD) and field emission scanning electron microscopy (FESEM) studies were performed in order to determine crystalline structure of P25 particles used for the present research.

\section{Materials and equipment}

Absorbance of water samples was measured with a Shimadzu UV1601 spectrophotometer and its own proprietary software, UVPC. Absorbance was measured, for every sample, from 200 to 800 $\mathrm{nm}$ with distillated water as baseline in $10 \mathrm{~mm}$ quartz cuvettes. Water samples $(3 \mathrm{~mL})$ were filtered on $0.45 \mu \mathrm{m}$ syringe filters in order to separate the photocatalyst particles from treated water. Acesulfame-K has an important (experimental) absorbance peak at $225 \mathrm{~nm}$, which was the wavelength used here to quantify the molecule. However, due to the fact that several of the initial intermediate compounds might keep the parent organic ring skeleton (López-Muñoz et al. 2018), whose absorbance peaks overlay with the acesulfame-K peak, kinetics and efficiency calculations are based on the ratio of absorbance at $t$ time divided by initial absorbance $\left(\mathrm{Abs} / \mathrm{Abs}_{0}\right)$ in order to consider the presence and the oxidation of these initial intermediate products. All of the glassware was class A, from Kimax and Pyrex. Glassware was cleaned with tap water (without detergent), rinsed with distilled water and dried. XRD was performed with a Siemens D500 diffractometer. A JEOL JSM7600F microscope, with an Oxford INCA XACT Energy-dispersive X-ray spectroscopy (EDS) analyzer, was used for FESEM microscopy and for chemical composition at the surface of catalyst particles. XRD patterns were analyzed with Crystal Impact software (Match! phase identification from powder diffraction). FESEM images were analyzed with the software Image J (US National Institute of Health). Chemical reactants and products were weighted on a Pioner (Ohaus) analytic balance.

The substances for the present work were acesulfame-K (Sigma-Aldrich, product 04054, assay of $100 \%$ according to its certificate of analysis); tri-distillated water (Química Asociados); sodium persulfate (Reasol, assay of $98 \%$ ); concentrated sulfuric acid (JT Baker México); sodium hydroxide (JT Baker México), and titanium dioxide (Aeroxide P25, Evonik).

\section{Photocatalytic solar reactor}

The reactor consisted of a set of $5 \mathrm{CPC}$ collectors with geometric concentration ratio equal to 1 , a set of 5 borosilicate glass pipes of $1000 \mathrm{~mm}$ (length) and $19 \mathrm{~mm}$ (outer diameter) connected in series, approaching a plug flow reactor (PFR) arrangement. Borosilicate pipes were placed at the focal region of the corresponding CPC collectors, in agreement with Baum and Gordon (1984). Each CPC collector consisted of a fiberglass support (from a 3D printed profile), covered by a Reflectek aluminum film. A total volume of $2 \mathrm{~L}$ of polluted water $(15 \mathrm{mg} / \mathrm{L}$ of acesulfame-K) was recirculated from a polyvinyl chloride (PVC) reservoir to the irradiated pipes along $180 \mathrm{~min}$, by a $35 \mathrm{~W}$ centrifugal pump with an open impeller. The set of pipes (reactor chamber) was set horizontally, with an east-west alignment. Reynolds number (Re) equal to 7741 was kept constant for the complete set of experiments, giving a mean residence time, inside glass pipes, of $13 \mathrm{~s}$. Solar ultraviolet irradiance (Guv) was measured on-site with a Lutron YK35UV radiometer. Main parts of the reactor are presented on figure 3.

Ultraviolet (UV) energy dose was calculated for each experiment according to the definition of ultraviolet insolation ( $\mathrm{H}_{\mathrm{UV}}$ ) from Duffie and Beckman (1980), presented on equation 1. The resolution of this equation for each reaction was performed numerically by Origin Pro v. 8 software. Experiments were performed in Cuautitlán Izcalli (Mexico City, $19.26^{\circ} \mathrm{N}, 99.8^{\circ} \mathrm{W}$ ), whose weather is classified as humid subtropical climate, from the Köppen climate classification (Britannica 2019). 


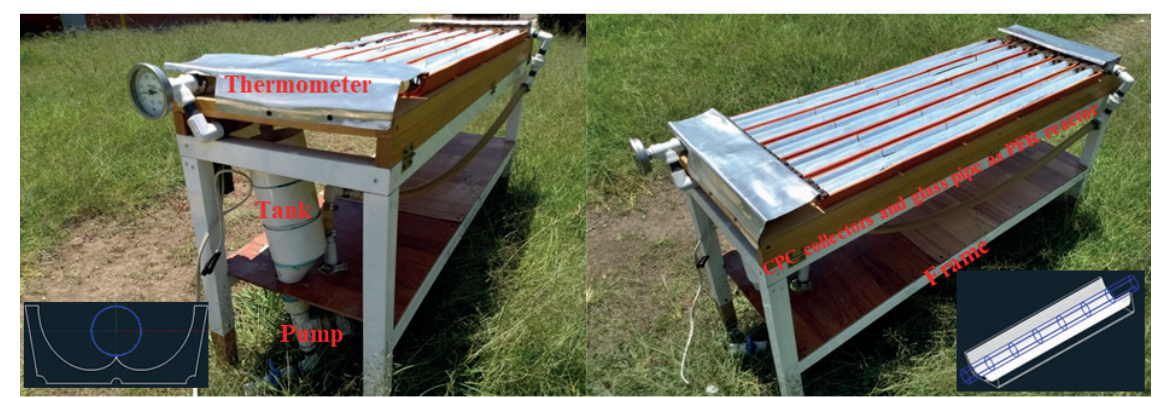

Fig. 3. Solar photocatalytic CPC reactor.

$H_{U V}=\int_{t=0}^{t} G_{U V} d t$

\section{RESULTS AND DISCUSSION}

\section{Photocatalyst characterization}

The catalyst was characterized in order to confirm its anatase content and particle diameters. FESEM images (Fig. 4) indicate that most of the P25 particles have quasi-spherical shapes (left) whose dimensions rounds 10 to $60 \mathrm{~nm}$, with an average of $28.59 \pm 8.55 \mathrm{~nm}$ (from FESEM images of 20 aleatory particles with $X=500000$ and $X=250$ 000). If an analysis was performed from an image with minor augmentation (e.g., Fig. 4), $\mathrm{TiO}_{2}$ particles from P25 might exhibit more homogeneous size and shape, but it must be considered that the higher the resolution the higher size variation of particles. This behavior is similar to the presented by Evonik (2018), whose researchers reported that their $\mathrm{TiO}_{2}$ nanomaterials have an average diameter ranging from 14 to $21 \mathrm{~nm}$; additionally, Khalid et al. (2018) measured P25 films and determined crystallite sizes from 14 to $34 \mathrm{~nm}$, indicating high possible variations among P25 samples. Ohtani et al. (2010) reported high variations from sample to sample (analysis of the same bag of product), and the difference could be explained by product lot to lot variations, and because the content of each lot might not be totally homogeneous (Datye et al. 1995, Ohno et al. 2001). XRD patterns (Fig. 5) show that the P25 catalyst used in this study has the corresponding anatase and rutile crystalline phases that are expected (Ohtani et al. 2010).

Chemical composition of P25 particles was directly obtained from EDS detector at FESEM microscope. An area analysis indicated that atomic percentages of $\mathrm{Ti}$ and $\mathrm{O}$ oscillated around $30.69 \pm$ 6.52 and $69.43 \pm 6.52 \%$, respectively. It is similar to what is expected from the pure molecule: one Ti atom and $2 \mathrm{O}$ atoms produce 33.33 and $66.66 \%$ (atomic) at $\mathrm{TiO}_{2}$ molecule.

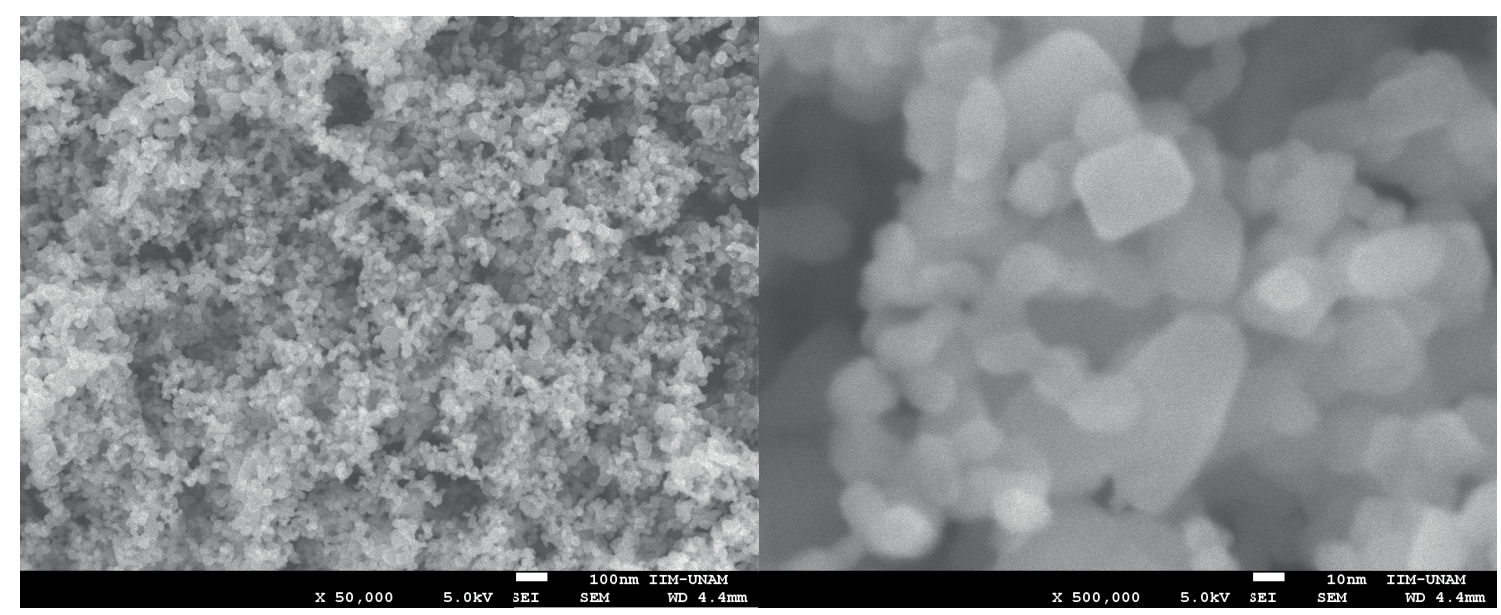

Fig. 4. FESEM images of $\mathrm{P} 25$ catalyst particles. 


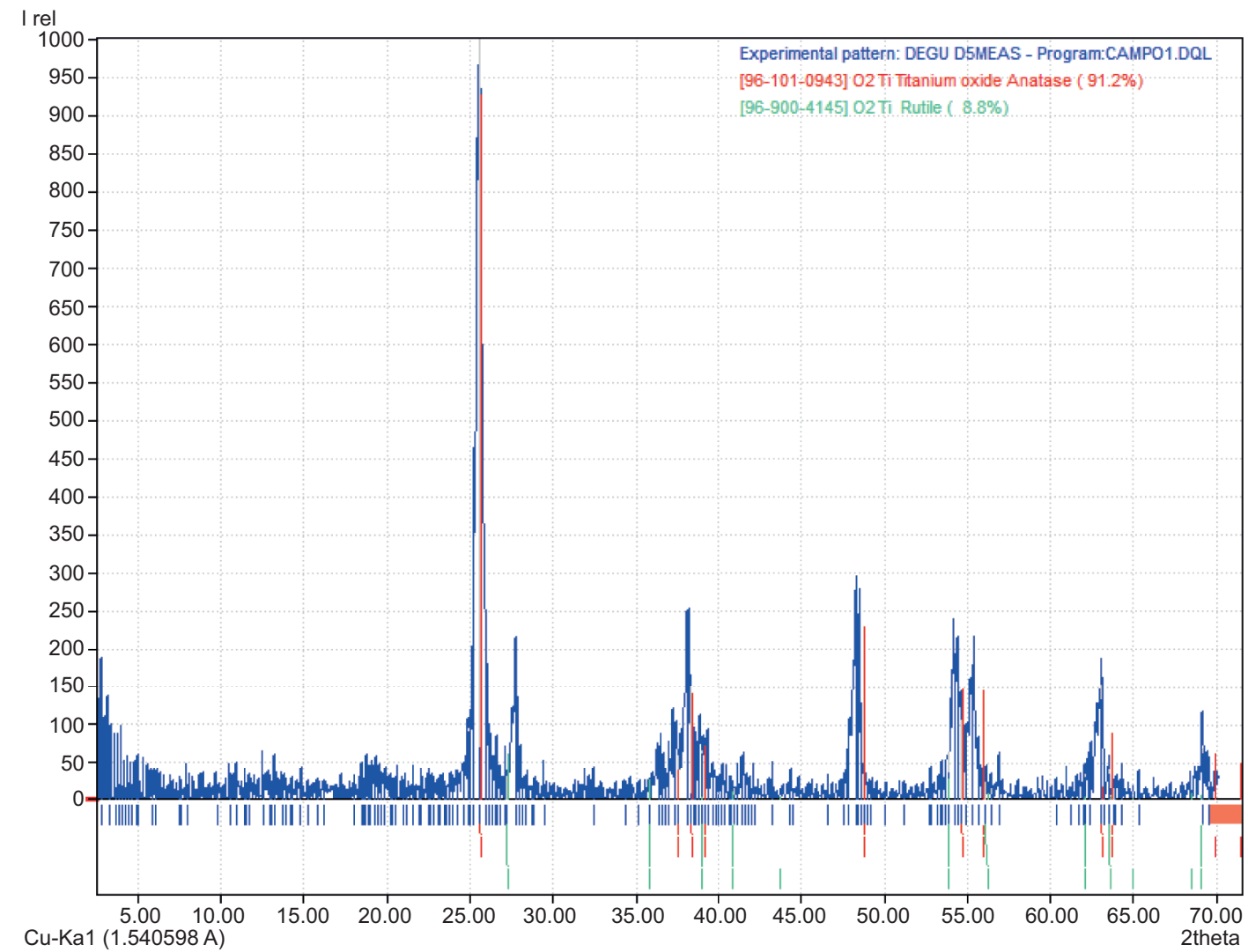

Fig. 5. Experimental XRD pattern of $\mathrm{P} 25$ catalysts sample and its fitting to anatase and rutile crystalline structures.

\section{Photocatalytic solar reactions}

The effects of initial $\mathrm{pH}$, initial $\mathrm{TiO}_{2}$ and initial persulfate on the oxidation of acesulfame- $\mathrm{K}$ are analyzed by pairs. Then, $\mathrm{pH}$-persulfate, $\mathrm{pH}-\mathrm{TiO}_{2}$ and persulfate- $\mathrm{TiO}_{2}$ data sets were compared by a two way ANOVA and some post-hoc tests. Photocatalytic oxidation reactions under solar UV irradiance were completed with high efficiencies, higher than $96 \%$ in all cases.

Reaction kinetics was based on UV energy dose, instead of time, because reaction time is inadequate for comparisons of reactions performed along different days or on different reactors. Several works on solar photocatalysis have been based on reaction energy dose, but only with an approximate determination of its value, because a simplified expression has been adopted as presented in equation 2 (Blanco 2003, Seck et al. 2013):

$$
E(\mathrm{t})=E\left(\mathrm{t}_{0}\right)+\Delta t \cdot \overline{G_{U V}}
$$

In equation 2, where $E(t)$ is the energy dose, $t$ is time, and $\overline{G_{U V}}$ is the average UV irradiance along calculation time, an important limitation is detected: solar UV irradiance has a linear response to time only for short periods. If measurements were performed within short times, error might not be very important with equation 2 . If measurements are done every 15-20 minutes, errors on the calculated $E(t)$ become important. A more accurate expression for $E(t)$ can be written as it is presented in equation 1 (Blanco 2003, Morales-Mejía et al. 2014b). This function for $E(t)$ can be solved either analytically or numerically. For the present study, as UV irradiance $\left(G_{\mathrm{UV}}\right)$ comes from the Sun and it presents hourly variations, the solution for $E(t)$ in equation 1 was achieved numerically from instantaneous irradiance data integrated over reaction times, with Origin Pro v. ${ }^{\circ} 8$ software.

A representative example of the initial $\mathrm{pH}$ effect $\left(\mathrm{TiO}_{2}\right.$ and persulfate concentrations were kept constant at $0.1 \mathrm{~g} / \mathrm{L}$ and $0.00025 \mathrm{M}$, respectively) on the photocatalytic oxidation efficiency is presented in figure 6 (left). According with ANOVA tests, there was not a clear difference in removal efficiencies among initial $\mathrm{pH}$ values for these tests; however, it can be observed that reactions performed at $\mathrm{pH}=9$ ended with a higher absorbance before reaching an UV dose of $150 \mathrm{~kJ} / \mathrm{m}^{2}$. For the rest of the tests, the 


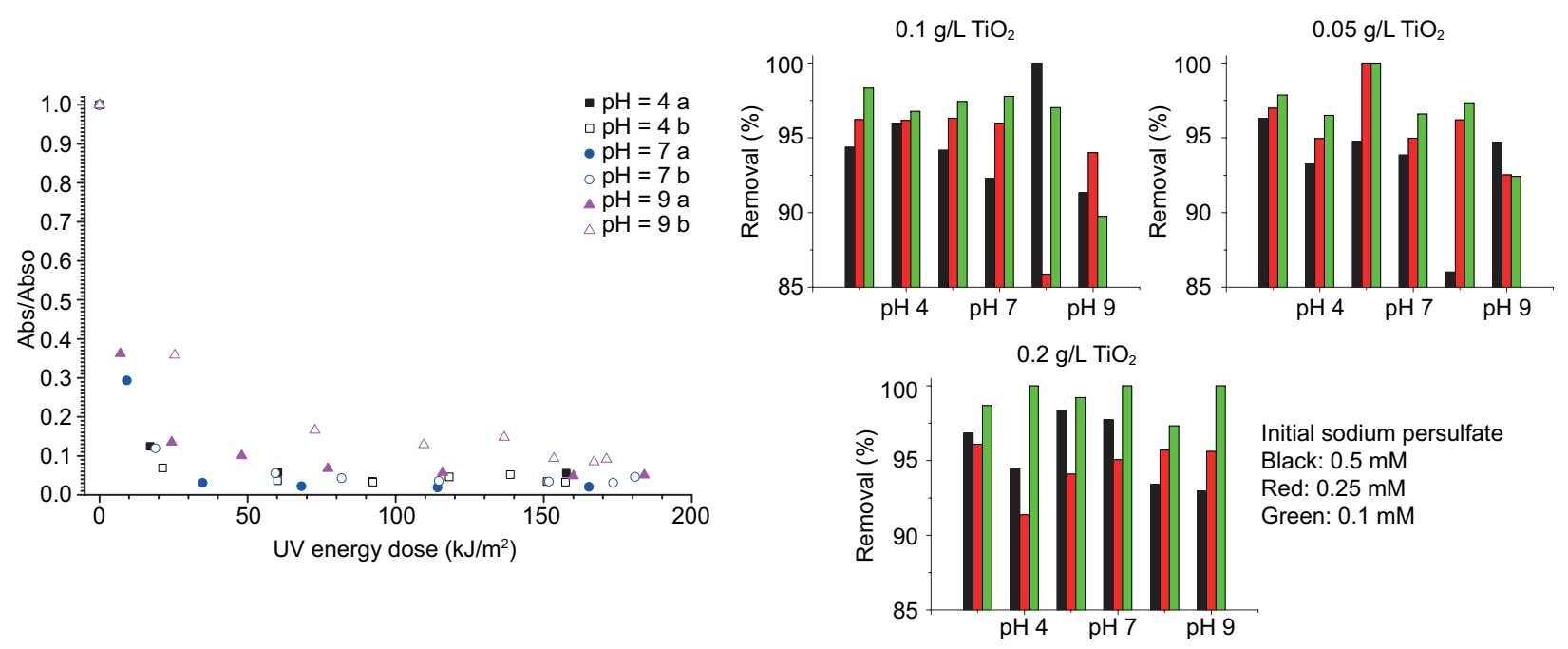

Fig. 6. Normalized absorbance for representative reactions at three different initial $\mathrm{pH}$ values and $0.1 \mathrm{~g} / \mathrm{L}$ of $\mathrm{TiO}_{2}$ (left), and efficiencies of the set of reactions against initial $\mathrm{pH}$ and initial oxidant concentrations (right).

results obtained in the present research, summarized in figure 6 (right), indicate a homogeneous behavior of efficiencies.

ANOVA results indicate that the removal efficiencies are not significantly different among P25 initial concentrations. On the other hand, ANOVA indicates that efficiencies are significantly different among the three initial concentrations values of persulfate.

Descriptive statistics and ANOVA results are presented in table I for the analysis of the three possible combinations: initial $\mathrm{P} 25$-initial persulfate, initial persulfate-initial $\mathrm{pH}$, and initial $\mathrm{pH}$-initial $\mathrm{P} 25$. The tests for the three combinations of variables indicate that there is a significant effect of both initial persulfate and of initial $\mathrm{pH}$; on the other hand, there is not significant effect of $\mathrm{TiO}_{2}(\mathrm{P} 25)$ dosage.

From the post hoc tests it is affirmed that initial persulfate concentration of $0.1 \mathrm{mM}$ gives different oxidation efficiency than 0.25 and $0.05 \mathrm{mM}$ of persulfate; in addition, initial $\mathrm{pH}$ plays a significant role on efficiency as well: removal efficiencies at $\mathrm{pH}=$ 7 and $\mathrm{pH}=4$ were not different; but efficiencies at $\mathrm{pH}=9$ and $\mathrm{pH}=7$ were different and there was a slightly difference among $\mathrm{pH}=4$ and $\mathrm{pH}=7$ (some tests indicated significance of 1 , while other tests significance equal to 0 ).

There are just a few published studies about photocatalytic oxidation of aqueous acesulfame-K. Ghosh et al. (2018b) worked with a Pyrex glass reactor (laboratory size, $150 \mathrm{~mL}$ of water, $10-50 \mathrm{mg} / \mathrm{L}$ of acesulfame-K, and $0.2-1.5 \mathrm{~g} / \mathrm{L}$ of P25) inside a solar simulator irradiating $100 \mathrm{~mW} / \mathrm{cm}^{2}$, with a visible filter. They removed the sweetener from 80 to $100 \%$ during $30 \mathrm{~min}$ of reaction and found that the photocatalytic oxidation of this molecule under artificial light fitted pseudo first order kinetics and that efficiency was directly proportional to $\mathrm{TiO}_{2}$ concentration and light intensity, but inversely related to initial acesulfame-K concentration. It is important to consider that $100 \mathrm{~mW} / \mathrm{cm}^{2}$ of UV light is 17 times (or even more) higher than solar UV irradiance (FoyoMoreno et al. 2003, Navntoft et al. 2012, SalgadoTránsito et al. 2015). Calza et al. (2017) worked with cerium-doped $\mathrm{ZnO}$ in a $50 \mathrm{~mL}$ cylindrical quartz glass reactor, reaching removal efficiencies up to 65 $\%$ with both P25 and their catalysts, under $750 \mathrm{~W} /$ $\mathrm{m}^{2}$ of artificial UV irradiance. Jing-Li et al. (2016) worked on photocatalytic oxidation of an aqueous solution of acesulfame- $\mathrm{K}$ at initial concentration of $400 \mathrm{mg} / \mathrm{L}$, reaching up to $99.99 \%$ of removal by irradiating a laboratory reactor with a UVC lamp, $19 \mathrm{~h}$ of reaction and $8 \mathrm{~g} / \mathrm{L}$ of $\mathrm{TiO}_{2}$ as catalyst $(25$ $\mathrm{mL}$ of water treated). López-Muñoz et al. (2018) studied three photocatalysts based on $\mathrm{TiO}_{2}$ (including P25) for removing acesulfame-K, treating $5 \mathrm{~mL}$ of an aqueous solution $(10 \mathrm{mg} / \mathrm{L})$ in quartz cells, with $1 \mathrm{~g} / \mathrm{L}$ of catalyst (the system was irradiated by a UVA lamp of $40 \mathrm{~W}$ ). The sweetener was removed within the first $30 \mathrm{~min}$ of reaction with each of the catalysts. The removal efficiencies obtained in the present research are very competitive (94 to $97 \%$ as averaged results) in comparison with those previously reported, because present removals were reached with UV energy doses as low as $40 \mathrm{~kJ} / \mathrm{m}^{2}$, under real 
TABLE I. DESCRIPTIVE STATISTIC AND ANOVA RESULTS OF THE EFFICIENCIES FOR PHOTOCATALYTIC OXIDATION OF ACESULFAME-K ( $=18$ FOR EACH LINE OF COMPARISONS)

\begin{tabular}{|c|c|c|c|c|c|c|c|c|}
\hline \multicolumn{3}{|c|}{ Initial P25 $\left(\mathrm{TiO}_{2}\right)$-initial persulfate } & \multicolumn{3}{|c|}{ Initial $\mathrm{pH}$-initial persulfate } & \multicolumn{3}{|c|}{ Initial pH.initial P25 $\left(\mathrm{TiO}_{2}\right)$} \\
\hline $\mathrm{TiO}_{2}$ & Mean & $\mathrm{SD}$ & $\mathrm{pH}$ & Mean & $\mathrm{SD}$ & $\mathrm{pH}$ & Mean & SD \\
\hline $0.1 \mathrm{~g} / \mathrm{L}$ & 94.99 & 3.41 & $\mathrm{pH} 4$ & 96.17 & 2.02 & $\mathrm{pH} 4$ & 96.17 & 2.02 \\
\hline $0.05 \mathrm{~g} / \mathrm{L}$ & 95.29 & 3.18 & pH 7 & 96.59 & 2.36 & $\mathrm{pH} 7$ & 96.59 & 2.37 \\
\hline $0.2 \mathrm{~g} / \mathrm{L}$ & 96.49 & 2.62 & $\mathrm{pH} 9$ & 94.01 & 4.02 & $\mathrm{pH} 9$ & 94.01 & 4.02 \\
\hline Persulfate & Mean & $\mathrm{SD}$ & Persulfate & Mean & SD & $\mathrm{TiO}_{2}$ & Mean & SD \\
\hline $0.5 \mathrm{mM}$ & 94.49 & 3.06 & $0.5 \mathrm{mM}$ & 94.49 & 3.06 & $0.1 \mathrm{~g} / \mathrm{L}$ & 94.99 & 3.41 \\
\hline $0.25 \mathrm{mM}$ & 94.90 & 2.89 & $0.25 \mathrm{mM}$ & 94.90 & 2.89 & $0.05 \mathrm{~g} / \mathrm{L}$ & 95.29 & 3.18 \\
\hline \multirow[t]{2}{*}{$0.1 \mathrm{mM}$} & 97.39 & 2.64 & $0.1 \mathrm{mM}$ & 97.39 & 2.64 & $0.2 \mathrm{~g} / \mathrm{L}$ & 96.49 & 2.62 \\
\hline & $\mathrm{F}$ & $P$ & & $\mathrm{~F}$ & $\mathrm{P}$ & & $\mathrm{F}$ & $\mathrm{P}$ \\
\hline Factor $\mathrm{A}, \mathrm{TiO}_{2}$ & 1.43 & 0.25 & Factor A, pH & 4.44 & 0.02 & Factor A, pH & 3.88 & 0.03 \\
\hline Factor B, persulfate & 5.56 & 0.01 & Factor B, persulfate & 5.72 & 0.01 & Factor $\mathrm{B}, \mathrm{TiO}_{2}$ & 1.28 & 0.29 \\
\hline Interaction & 1.16 & 0.34 & Interaction & 0.05 & 1.00 & Interaction & 0.48 & 0.75 \\
\hline
\end{tabular}

solar irradiance (around 20-30 minutes of reaction) and with a ratio of $5 \mathrm{~L}$ of water per square meter of collecting reflectors.

\section{CONCLUSIONS}

- Acesulfame-K was efficiently removed from water by the usage of a pilot solar photocatalytic $\mathrm{CPC}$ reactor designed with unitary geometrical concentration ratio. Removal efficiencies were $94 \%$ or higher.

- The photocatalyst used for the present work presented a spherical shape, average particle diameter of $28.59 \mathrm{~nm}$, anatase and rutile particles, and high purity. These properties are in accordance with the values reported on scientific and technical literature.

- Removal efficiency was influenced by both initial $\mathrm{pH}$ and initial sodium persulfate concentration, but it was not by catalyst load on the ranges that have been studied in the present work.

- The best $\mathrm{pH}$ values to remove acesulfame-K were 4 and 7. At basic $\mathrm{pH}$ values, the efficiency significantly decreased.

- The best initial concentration of persulfate resulted in $0.1 \mathrm{mM}$.

- Initial $\mathrm{TiO}_{2}$ concentration did not present important influence on removal efficiencies for the range of 0.05 to $0.2 \mathrm{~g} / \mathrm{L}$.

- Although the initial catalyst concentration did not influence efficiency significantly (according to post hoc tests), it was verified that slightly higher removals were reached with $0.2 \mathrm{~g} / \mathrm{L}$ of P25 in comparison to $0.1 \mathrm{~g} / 1$ and $0.05 \mathrm{~g} / \mathrm{L}$ catalyst loads in the reactor (without significant difference).

- Results indicate that it is possible to reduce the mass of catalyst up to $0.05 \mathrm{~g} / \mathrm{L}$ or even less, keeping high removal efficiencies.

\section{ACKNOWLEDGMENTS}

Authors acknowledge the Dirección General de Asuntos del Personal Académico of UNAM for its financial support through project PAPIIT IA106216 (Tratamiento fotocatalítico solar de agua con contaminantes no biodegradables tipo ECP encontrados en México). Also, authors thank Ana Leticia Fernández (XRD Laboratory, Facultad de Estudios Superiores Cuautitlánm, UNAM), as well as Omar Novelo Peralta and Josué Esaú Romero Ibarra (LUME Laboratory, Instituto de Investigaciones en Materiales, UNAM) for the XRD, FESEM and EDS studies.

\section{REFERENCES}

Albrbar A.J, Djokić V., Bjelajac A., Kovač J., Ćirković J., Mitrić M., Janaćković D. and Petrović R. (2016). Visible-light active mesoporous, nanocrystalline N, Sdoped and co-doped titania photocatalysts synthesized by non-hydrolytic sol-gel route. Ceram. Int. 42, 1671816728. https://doi.org/10.1016/j.ceramint.2016.07.144 Arzate-Salgado S., Ramírez-Zamora R.M., Zanella R., Peral J., Malato S. and Maldonado M.I. (2016). 
Photocatalytic hydrogen production in a solar pilot plant using an $\mathrm{Au} / \mathrm{TiO}_{2}$ photo catalyst. Int. J. Hydrogen Energ. 41 (28), 11933-11940. https://doi.org/10.1016/j. ijhydene.2016.05.039

Baum H.P. and Gordon J.M. (1984). Geometric characteristics of ideal non-imaging (CPC) solar collectors with cylindrical absorber. Sol. Energy 33 (5), 455-458. https://doi.org/10.1016/0038-092X(84)90198-1

Blanco J. (2003). Desarrollo de colectores solares CPC para aplicaciones fotoquímicas de degradación de contaminantes persistentes en agua. Colecciones documentos Ciemat. Ministerio de Ciencia y Cultura. Madrid, España, 277 pp.

Britannica (2019). Humid subtropical climate climatology. Encyclopedia Britannica [on-line]. https://www.britannica.com/science/humid-subtropical-climate 28/11/19.

Buerge I.J., Buser H.R., Kahle M., Müller M.D. and Poiger T. (2009). Ubiquitous occurrence of the artificial sweetener acesulfame in the aquatic environment: An ideal chemical marker of domestic wastewater in groundwater. Environ Sci. Technol. 43 (12), 43814385. https://doi.org/10.1021/es900126x

Calza P., Gionco C., Giletta M., Kalaboka M., Sakkas V.A., Albanis T. and Paganini M.C. (2017). Assessment of the abatement of acelsulfame $\mathrm{K}$ using cerium doped $\mathrm{ZnO}$ as photocatalyst. J. Hazard. Mater. 323, 471-477. https://doi.org/10.1016/j.jhazmat.2016.03.093

Colón G., Maicua M., Hidalgo M.C., Navío J.A., Kubacka A. and Fernández-García M. (2010). Gas phase photocatalytic oxidation of toluene using highly active $\mathrm{Pt}$ doped $\mathrm{TiO}_{2}$. J. Mol. Catal. A-Chem. 320, 14-18. https:// doi.org/10.1016/j.molcata.2009.12.009

Cruz-Rojas C., San Juan-Reyes N., Fuentes-Benites M., Dublan-García O., Galar-Martínez M., Islas-Flores H. and Gómez-Oliván L. (2019). Acesulfame potassium: Its ecotoxicity measured through oxidative stress biomarkers in common carp (Cyprinus carpio). Sci. Total Environ. 647, 772-784. https://doi.org/10.1016/j. scitotenv.2018.08.034

Datye A.K., Riegel G., Bolton J.R., Huang M. and Prairie M.R. (1995). Microstructural characterization of a fumed titanium dioxide photocatalyst. J. Solid State. Chem. 115 (1), 236-239. https://doi.org/10.1006/ jssc. 1995.1126

Duffie J.A. and Beckman W.A. (1980). Available solar radiation. In: Solar engineering of thermal processes. Wiley Interscience, New York, USA, pp. 43-137.

Durán-Álvarez J.C, Hernández-Morales V.A., RodríguezVarela M., Guerrero-Araque D., Ramírez-Ortega D., Castillón F., Acevedo-Peña P. and Zanella R. (2019). $\mathrm{Ag}_{2} \mathrm{O} / \mathrm{TiO}_{2}$ nanostructures for the photocatalytic mineralization of the highly recalcitrant pollutant iopromide in pure and tap water. Catal. Today 341,
71-81. https://doi.org/https://doi.org/10.1016/j.cattod.2019.01.027

Evonik (2018). Aeroxide, Aerodisp and Aeroperl titanium dioxide as photocatalyst. Technical information 1243 [on line].https://www.silica-specialist.com/product/ aerosil/downloads/ti-1243-titanium-dioxide-as-photocatalyst-en.pdf 25/07/18.

FDA (2018). Additional Information about high-intensity sweeteners permitted for use in food in the United States. U.S. Food and Drug Administration (on line). https://www.fda.gov/Food/IngredientsPackagingLabeling/FoodAdditivesIngredients/ucm397725.htm 09/07/18.

Foyo-Moreno I., Alados I., Olmo F.J. and AladosArboledas L. (2003). The influence of cloudiness on UV global irradiance (295-85 nm). Agr. Forest. Meteorol. 120, 101-111. https://doi.org/10.1016/j. agrformet.2003.08.023

Gan Z., Sun H., Feng B., Wang R. and Zhang Y. (2013). Occurrence of seven artificial sweeteners in the aquatic environment and precipitation of Tianjin, China. Water Res. 47, 4928-4937. https://doi.org/10.1016/j. watres.2013.05.038

Gan Z., Sun H., Wang R., Hu H., Zhang P. and Ren X. (2014). Transformation of acesulfame in water under natural sunlight: Joint effect of photolysis and biodegradation. Water Res. 64, 113-122. https://doi. org/10.1016/j.watres.2014.07.002

Gosh S., Mallik A. and Basu R. (2018a). Enhanced photocatalytic activity and photoresponse of poly(3,4-ethylenedioxythiophene) nanofibers decorated with gold nanoparticle under visible light. Sol. Energy. 159, 548-560. https://doi.org/10.1016/j. solener.2017.11.036

Ghosh M., Chowdhury P. and Ray A.K. (2018b). Study of solar photocatalytic degradation of acesulfame $\mathrm{K}$ to limit the outpouring of artificial sweeteners. Sep. Purif. Technol. 207 (22), 51-57. https://doi.org/10.1016/j. seppur.2018.05.062

Hernández-Colorado P., Pinto S., Morales-Mejía J.C., Vargas-Rodríguez Y., Delgadillo-García G. and Almanza R. (2017). Photocatalytic oxidation of aqueous naproxen with a horizontally placed solar CPC slurry reactor. Desalin Water Treat. 67, 159-167. https://doi. org/10.5004/dwt.2017.20723

Herrmann J.M. (2005). Heterogeneous photocatalysis: State of the art and present applications. Top Catal. 34 (1-4), 49-6. https://doi.org/10.1007/s11244-005$3788-2$

Herrmann J.M. (2010). Fundamentals and misconceptions in photocatalysis. J. Photoch. Photobio. AChem. 216, 85-93. https://doi.org/10.1016/j.jphotochem.2010.05.015 
IPCS (2018). Acesulfame potassium (INCHEM data). International Programme on Chemical Safety, World Health Organization [on line]. http://www.inchem. org/documents/jecfa/jecmono/v16je02.htm 09/07/18.

Jing-Li A., Schmitz O.J., Stephan S., Lenzen C., Ying-Kit P., Li K., Li H. and Sze-Yin K. (2016). Photocatalytic transformation of acesulfame: Transformation products identification and embryotoxicity study. Water Res. 89, 68-75. https://doi.org/10.1016/j.watres.2015.11.035

Kaur T., Sraw A., Wanchoo R.K. and Toor A.P. (2018). Solar assisted degradation of carbendazim in water using clay beads immobilized with $\mathrm{TiO}_{2} \& \mathrm{Fe}$ doped $\mathrm{TiO}_{2}$. Sol. Energy. 162, 45-56. https://doi.org/10.1016/j. solener.2017.11.033

Khalid M., Mortuza A.A., Sen S.K., Basher M.K., Ashraf M.W., Tayyaba S., Mia M.N.H. and Jalal M. (2018). A comparative study on the influence of pure anatase and Degussa- $\mathrm{P} 25 \mathrm{TiO}_{2}$ nanomaterials on the structural and optical properties of dye sensitized solar cell (DSSC) photoanode. Optik 171, 507-516. https://doi. org/10.1016/j.ijleo.2018.05.032

Khan H., Jiang Z. and Berk D. (2018). Molybdenum doped graphene/ $\mathrm{TiO}_{2}$ hybrid photocatalyst for UV/ visible photocatalytic applications. Sol. Energy. 162, 420-430. https://doi.org/10.1016/j.solener.2018.01.055

Lee S.H., Yamasue E., Okumura H. and Ishihara K. (2009). Effect of oxygen and nitrogen concentration of nitrogen doped $\mathrm{TiO}_{\mathrm{x}}$ film as photocatalyst prepared by reactive sputtering. Appl. Catal. A-Gen. 371, 179-190. https:// doi.org/10.1016/j.apcata.2009.10.011

Li-Puma J.L. (2005). Dimensionless analysis of photocatalytic reactors using suspended solid photocatalysts. Chem. Eng. Res. Des. 83 (A7), 820-826. https://doi. org/10.1205/cherd.04336

López-Muñoz M.J., Daniele A., Zorzi M., Medana C. and Calza P. (2018). Investigation of the photocatalytic transformation of acesulfame $\mathrm{K}$ in the presence of different $\mathrm{TiO}_{2}$-based materials. Chemosphere 193, 151159. https://doi.org/10.1016/j.chemosphere.2017.11.016

Ma Y., Fu J., Tao X., Li X. and Chen J.F. (2011). Low temperature synthesis of iodine-doped $\mathrm{TiO}_{2}$ nanocrystallites with enhanced visible-induced photocatalytic activity. Appl. Surf. Sci. 257, 5046-5051. https://doi. org/10.1016/j.apsusc.2011.01.019

Moeder M., Carranza-Díaz O., López-Angulo G., VegaAviña R., Chávez-Durán F., Jomaa S., Winkler U., Schrader S., Reemtsma T. and Delgado-Vargas F. (2017). Potential of vegetated ditches to manage organic pollutants derived from agricultural runoff and domestic sewage: A case study in Sinaloa (Mexico). Sci. Total Environ. 598, 1106-1115. https://doi. org/10.1016/j.scitotenv.2017.04.149
Morales-Mejía J.C., Ángeles L. and Almanza R. (2013). Thick $\mathrm{TiO}_{2}$ sol-gel films for water detoxification: Synthesis, characterization and use for photocatalytic oxidation. J. Adv. Oxid. Technol. 16 (2), 224-233. https://doi.org/10.1515/jaots-2013-0202

Morales-Mejía J.C. (2014a). Uso de colectores solares para la remoción fotocatalítica de disruptores endócrinos presentes en agua contaminada. Ph.D. thesis. Facultad de Ingeniería, Universidad Nacional Autónoma de México. Ciudad de México, Mexico, 204 pp.

Morales-Mejía J.C., Almanza R. and Santiago L. (2014b). Irradiancia UVA solar sobre superficies inclinadas $19.4^{\circ}$ y fijas en el sur de la Ciudad de México. Proceedings. XXXVIII Semana Nacional de Energía Solar y XI Congreso Iberoamericano. Querétaro, Mexico. April 6-10, 2014. CD ROM.

Navntoft L.C., Fernandez-Ibañez P. and Garreta F. (2012). UV solar radiation on a tilted and horizontal plane: Analysis and comparison of 4 years of measurements. Sol. Energy 86, 307-318. https://doi.org/10.1016/j. solener.2011.10.004

Nezar S. and Laoufi N.A. (2018). Electron acceptors effect on photocatalytic degradation of metformin under sunlight irradiation. Sol. Energy 164, 267-275. https:// doi.org/10.1016/j.solener.2018.02.065

Ohno T., Sarukawa K., Tokieda K. and Matsumura M. (2001), Morphology of a $\mathrm{TiO}_{2}$ photocatalyst (Degussa, P-25) consisting of anatase and rutile crystalline phases. J. Catal. 203 (1), 82-86. https://doi.org/10.1006/jcat.2001.3316

Ohtani B., Prieto-Mahaney O.O., Li D. and Abe R. (2010). What is Degussa (Evonik) P25? Crystalline composition analysis, reconstruction from isolated pure particles and photocatalytic activity test. J. Photoch. Photobio. A-Chem. 216, 179182. https://doi. org/10.1016/j.jphotochem.2010.07.024

Salgado-Tránsito I., Jiménez-González A.E., RamónGarcía M.L. and Estrada-Gasca C.A. (2015). Design of a novel CPC collector for the photodegradation of carbaryl pesticides as a function of the solar concentration ratio. Sol. Energy 115, 537-551. https://doi. org/10.1016/j.solener.2015.02.034

Sang Z., Jiang Y., Tsoi Y. and Leung K. (2014). Evaluating the environmental impact of artificial sweeteners: A study of their distributions, photodegradation and toxicities. Water Res. 52, 260274. https://doi. org/10.1016/j.watres.2013.11.002

Scheurer M., Schmutz B., Happel O., Brauch H., Wülser R. and Storck F. (2014). Transformation of the artificial sweetener acesulfame by UV light. Sci. Total Environ. 481, 425-432. https://doi.org/10.1016/j. scitotenv.2014.02.047

SE (2018). Analysis of the economic, technological and market policy status of the sweetener sector in Mexico. 
Ministry of Economy, Mexico [on line]. http://www. economia.gob.mx/files/en/data_and_research/sweetener_sector.pdf 09/07/18.

Seck E.I., Doña-Rodríguez J.M., Fernández-Rodríguez C., Portillo-Carrizo D., Hernández-Rodríguez M.J., González-Díaz O.M. and Pérez-Peña J. (2013). Solar photocatalytic removal of herbicides from real water by using sol-gel synthesized nanocrystalline $\mathrm{TiO}_{2}$ : Operational parameters optimization and toxicity studies. Sol. Energy 87, 150-157. https://doi.org/10.1016/j. solener.2012.10.015

Statista (2018). Number of people using artificial sweeteners in France from 2015 to 2016, by frequency [on line]. https://www.statista.com/statistics/458432/ artificial-sweeteners-usage-by-frequency-in-france/ 09/07/2018.
Sylvetsky A.C., Jin Y., Clark E.J., Welsh J.A., Rother K.I. and Talegawkar S.A. (2017). Consumption of lowcalorie sweeteners among children and adults in the United States. J. Acad. Nutr. Diet. 117 (3), 441-448. https://doi.org/10.1016/j.jand.2016.11.004

Wang Q., Xu S. and Shen F. (2011). Preparation and characterization of $\mathrm{TiO}_{2}$ photocatalysts co-doped with iron (III) and lanthanum for the degradation of organic pollutants. Appl. Surf. Sci. 257, 7671-7677. https://doi. org/10.1016/j.apsusc.2011.03.157

Wang W.K., Chen J., Gao M., Huang Y., Zhang X. and Yu H. (2016). Photocatalytic degradation of atrazine by boron-doped $\mathrm{TiO}_{2}$ with a tunable rutile/anatase ratio. Appl. Catal. B-Environ. 195, 69-76. https://doi. org/10.1016/j.apcatb.2016.05.009. 